\title{
Analisis Technology Readiness Acceptance Penggunaan Komputer dan Teknologi Informasi Pada Manajemen Proyek Kontraktor
}

\author{
R Panday ${ }^{*}$, A Wibowo ${ }^{2}$, S Mardiah ${ }^{3}$ \\ 1,2,3,Fakultas Ekonomi, Universitas Bhayangkara Jakarta Raya, \\ indripan @gmail.com
}

\begin{abstract}
ABSTRAK
Teknologi informasi dan pemrosesan data menggunakan komputer adalah yang paling banyak digunakan dalam suatu proyek. Untuk itu dibutuhkan karyawan yang sudah siap dan dapat menerima teknologi. Ketidak kesiapan dan tidak menerima teknologi, akan berdampak pada kinerja proyek. Penelitian ini bertujuan untuk menganalisis tingkat kesiapan teknologi dan tingkat penerimaan teknologi karyawan pada proyek dengan menerapkan model TRAM. Data penelitian diambil menggunakan kuesioner, dengan responden adalah karyawan proyek yang menggunakan teknologi informasi dan pemrosesan data komputer di PT. DENKI, sebanyak 100 responden. Pengolahan data menggunakan analisis jalur. Hasil penelitian menunjukkan bahwa Optimisme berpengaruh positif dan siknifikan terhadap persepsi kemudahan penggunaan dan persepsi kegunaan. Keinovasian berpengaruh positif dan siknifikan terhadap persepsi kemudahan penggunaan. Ketidakamanan berpengaruh negatif dan siknifikan terhadap persepsi kemudahan penggunaan. Persepsi kemudahan penggunaan berpengaruh positif dan siknifikan terhadap persepsi kegunaan. Berdasarkan hasil tersebut, perusahaan harus merencanakan strategi pengembangan karyawan, dalam rangka meningkatkan kesiapan teknologi dan penerimaan teknologi karyawan, sehingga operasi manajemen proyek akan lebih baik.
\end{abstract}

Kata Kunci: Kesiapan Teknologi, Penerimaan Teknologi, Analisis Jalur

\begin{abstract}
Information technology and data processing using computers are the most widely used in a project. For this reason, it requires employees who are ready and able to accept technology. Not readiness and not accepting technology will have an impact on project performance. This study aims to analyze the level of technological readiness and the level of technology acceptance of employees on the project by implementing the TRAM model. The research data was taken using a questionnaire, with respondents being project employees who used information technology and computer data processing at PT. DENKI, as many as 100 respondents. Processing data using path analysis. The results showed that optimism had a positive and significant effect on perceived ease of use and perceived of usefulness. Innovativeness has a positive and significant effect on perceived ease of use. Insecurity has a negative and significant effect on perceived ease of use. Perceived ease of use has a positive and significant effect on the perceived of usefulness. Based on these results, companies must plan employee development strategies, in order to improve technology readiness and acceptance of employee technology, so that project management operations will be better.
\end{abstract}

Keywords: Technology Readiness, Technology Acceptance, Path Analysis

Diterima: 20 Nov 2018; Direvisi: 21 Jan 2019; Diterbitkan: 15 April 2019 


\section{LATAR BELAKANG}

Saat ini Teknologi Informasi Komunikasi (TIK), baik hardware maupun software telah digunakan dalam setiap kegiatan/ organisasi, baik sebagian maupun secara keseluruhan (Panday, 2015b). Berbagai bentuk hardware dan software telah berkembang dengan pesat. TIK modern telah menjadi semakin menonjol dan penting dalam aktivitas manusia. TIK merupakan bagian dari sistem input-prosesoutput dari sistem operasional suatu kegiatan / organisasi. Dengan menggunakan TIK diharapkan dapat meningkatkan produktivitas, dan hasilnya lebih akurat, disampaikan dengan cepat dan memuaskan (Panday, 2015c). Oleh karena itu, TIK digunakan juga untuk mengelola proyek, karena kegiatan proyek demikian banyak dan kompleks. Kegiatan proyek dapat berupa proyek fisik meliputi bangunan, jalan tol, bendungan, bandara, pelabuhan, kota dll, dan proyek non fisik meliputi pendidikan, pelatihan, kesehatan, budaya dll. Dalam hal ini, proyek didefinisikan sebagai kegiatan untuk membangun atau membuat sesuatu yang memberi manfaat bagi organisasi atau orang, yang menggunakan anggaran terbatas, waktu dan mengacu pada spesifikasi tertentu (Kerzner, 1998 ;Meredith, Jack.R and Mantel, 1995;Nicholas, 1990). Karena pekerjaan di dalam proyek demikian kompleksnya, maka untuk menyelesaikan proyek, diperlukan pengetahuan manajemen proyek; yaitu sebagai penerapan pengetahuan, keterampilan, alat dan teknik untuk kegiatan proyek dalam rangka memenuhi atau melampaui kebutuhan dan harapan pemangku kepentingan dari suatu proyek (PMBOK Guide, 1996). Untuk mendukung manajemen operasi tersebut, akan lebih baik menggunakan TIK. Operasi proyek yang dapat didukung oleh TIK, meliputi: manajemen data (personil, bahan, peralatan), pemrosesan data (menggambar, data teknik, statistik), presentasi data (laporan proyek untuk semua tingkat manajemen), dan pengiriman data/penyampaian data kepada banyak pemegang kepentingan proyek. Dengan menggunakan TIK, diharapkan kegiatan manajer proyek akan efektif dan efisien, sehingga tujuan proyek dapat tercapai. Akan tetapi, implementasi TIK masih tergantung pada orang/ operator TIK, dalam hal kesiapan teknologi, dan penerimaan teknologi orang/operator tersebut.

PT. DENKI, sebagai perusahaan kontraktor mekanikal dan elektrikal di kota Bekasi, sebagai bagian dari operasional manajemen proyek, telah menggunakan TIK, untuk mendukung pemrosesan data proyek seperti menggambar konstruksi, membuat jadwal proyek, aliran keuangan proyek, merekam barang yang masuk dan keluar, dan berkomunikasi secara elektronik. menggunakan email. Untuk alasan ini mereka membutuhkan personel yang mahir dalam menggunakan komputer dan perangkat lunak. Penggunaan teknologi komputer akan meningkatkan efisiensi dan efektivitas, dan pada akhirnya meningkatkan produktivitas dan kualitas kerja yang lebih baik. Akan tetapi, dalam operasi proyek, penggunaan TIK dengan komputernya masih belum optimal, dimana masih terjadi hal-hal berikut seperti: penyelesaian laporan masih lambat, pemrosesan data juga masih lambat, masih ada yang belum melek teknologi pada karyawan perusahaan, lambat dalam menggunakan perangkat lunak, menggunakan TIK masih tidak nyaman, karena mereka sudah terbiasa sepenuhnya menggunakan metode manual, masih lambat mentransformasikan diri dari karyawan yang bekerja secara manual menjadi karyawan yang bekerja menggunakan teknologi TIK. Setidaknya ada dua hal yang menyebabkan situasi terjadi, yaitu faktor internal karyawan dan faktor eksternal karyawan. Faktor internal pribadi, terkait dengan teknologi, telah dibahas oleh Parasuraman dan Davis dalam teori kesiapan teknologi dan penerimaan teknologi. Tujuan dari penelitian ini untuk menganalisis kesiapan teknologi dan penerimaan teknologi serta pengaruhnya di PT.DENKI? Bagaimana tingkat kesiapan teknologi dan tingkat penerimaan teknologi di PT. DENKI? Penelitian ini dapat memberikan manfaat bagi perusahaan untuk meningkatkan kesiapan teknologi dan penerimaan teknologi di PT. DENKI, dan akhirnya untuk meningkatkan kualitas kerja pada kegiatan proyek. 


\section{TINJAUAN PUSTAKA}

Kecekatan personel dalam menggunakan komputer, menurut Parasuraman tentang Technology Readiness Index (TRI), merupakan kemampuan seseorang dalam menggunakan teknologi, dapat dipengaruhi oleh 4 dimensi karakter yaitu Optimisme, Keinovasian, Ketidaknyamanan dan Ketidakamanan.

$>$ Optimisme didefinisikan sebagai "pandangan positif tentang teknologi dan keyakinan yang menawarkan kepada masyarakat peningkatan kontrol, fleksibilitas, dan efisiensi dalam kehidupan mereka"(Parasuraman, A., \& Colby, 2001). Secara umum menangkap perasaan positif tentang teknologi.

$>$ keinovasian didefinisikan "kecenderungan untuk menjadi pelopor teknologi dan berpikiran maju"(Parasuraman, A., \& Colby, 2001). Dimensi ini umumnya mengukur sejauh mana individu memandang diri mereka sebagai yang terdepan.

$>$ Ketidaknyamanan didefinisikan sebagai "kurangnya kontrol atas teknologi dan perasaan terbebani olehnya"(Parasuraman, A., \& Colby, 2001). Dimensi ini umumnya mengukur ketakutan dan kekhawatiran yang dialami orang ketika berhadapan dengan teknologi.

> Ketidakamanan didefinisikan sebagai "ketidakpercayaan terhadap teknologi dan skeptisisme tentang kemampuannya untuk bekerja dengan baik" (Parasuraman, A., \& Colby, 2001). Dimensi ini berfokus pada kekhawatiran yang mungkin dimiliki orang dalam menghadapi transaksi berbasis teknologi.

Optimisme dan inovasi disebut sebagai faktor pendorong kesiapan teknologi (Technology Readiness). Skor tinggi pada dimensi ini akan meningkatkan kesiapan teknologi secara keseluruhan. Di sisi lain, ketidaknyamanan dan ketidakamanan merupakan faktor penghambat kesiapan teknologi. Skor tinggi pada dimensi ini akan mengurangi kesiapan teknologi secara keseluruhan (Parasuraman, 2000a). Ke empat dimensi tersebut independen, masing-masing adalah unik terhadap kesiapan teknologi individu (Parasuraman, A., \& Colby, 2001). Penelitian yang ekstensif telah dilakukan di Amerika Serikat oleh (Parasuraman, 2000b), dan (Tsikriktsis, 2004) di Inggris, terkait dengan data reliabilitas untuk kesiapan teknologi, dengan banyak responden, menghasilkan kesimpulan yang sama tentang rentang nilai cronbach kesiapan teknologi. Teori lain yang digunakan dalam penelitian ini adalah model penerimaan teknologi (Technology Acceptance Model / TAM), yang diperkenalkan (Davis, 1989). Dalam TAM ada dua faktor penentu utama: Kegunaan yang dirasakan, yang mengacu pada "sejauh mana seseorang percaya bahwa menggunakan sistem tertentu akan meningkatkan kinerja pekerjaannya."(Davis, 1989); dan persepsi kemudahan penggunaan, yang mengacu pada "sejauh mana seseorang percaya bahwa menggunakan sistem tertentu akan bebas dari upaya"(Davis, 1989). TAM dirancang khusus untuk menjelaskan perilaku penggunaan komputer. Ini merupakan adaptasi dari (Fishbein, M., \& Ajzen, 1975) Teori Aksi Beralasan (Theory Reaction Action/TRA), yang telah berhasil memprediksi dan menjelaskan perilaku secara umum (Malhotra, Y., \& Galletta, 1999). Mengikuti dasar teoritis dari TRA, karakteristik yang dirasakan ini diharapkan mempengaruhi intensitas untuk menggunakan suatu sistem, yang pada akhirnya mempengaruhi penggunaan sistem aktual. (Davis, D., Bagozzi, R. P., \& Warshaw, 1989). Selanjutnya, persepsi kemudahan penggunaan dihipotesiskan untuk memengaruhi manfaat yang dirasakan. Hipotesis ini mengikuti logika bahwa perbaikan dalam kemudahan penggunaan sistem berkontribusi pada peningkatan kegunaan karena upaya yang sedikit (Davis, D., Bagozzi, R. P., \& Warshaw, 1989). TAM telah menerima banyak dukungan. Ini telah divalidasi melalui berbagai sistem, dan manfaat yang dirasakan dan kemudahan penggunaan yang dirasakan telah terbukti dapat diandalkan dan dimensi kognitif yang valid (Burton-Jones, A., \& Hubona, 2006) (King, W. R., \& He, 2006). Dalam studi ini digunakan TRI terintegrasi dengan TAM, yang "kecenderungan orang untuk merangkul dan menggunakan teknologi baru untuk mencapai tujuan dalam 
kehidupan rumah dan di tempat kerja" akan memprediksi penerimaan teknologi, dan selanjutnya akan mempengaruhi niat perilaku yang diwakili oleh penggunaan aktual. Model terintegrasi ini bernama TRAM (Technology Readiness-Acceptance Model). Model ini telah digunakan oleh beberapa peneliti seperti (Lin, C.-H., Shih, H.-Y., Sher, P. J., 2005), dan, (Venkatesh, 2000) dan ;(Schepers, J., \& Wetzels, 2007). TRAM telah digunakan juga oleh peneliti seperti :(Kuang-Ming Kuo, 2013), dimana penelitian mereka tentang sistem rekam medis elektronik bergerak yang dioperasikan oleh perawat;(Murat Esen, 2014), penelitian mereka tentang E-HRM; (Anders Husa, 2009), penelitian mereka tentang Konteks Media Sosial;(Mimin Nur Aisyah, Mahendra Adhi Nugroho, 2013), penelitian mereka pada komputer aplikasi di UMKM;(Yen, 2014), (Nadine Guhr, Tai Loi, Rouven Wiegard, 2013), penelitian mereka pada M(obile)-Payment; (Panday \& Purba, 2015) telah menggunakan kesiapan teknologi dalam menggunakan Sistem Informasi Akademik oleh mahasiswa dan dosen di universitas X. (Panday, 2015c) juga menggunakan TRAM untuk menguji model Sistem Informasi Akademik. (Panday, 2015a) juga menggunakan TRAM untuk menguji model pada siswa Geodesi dalam pemrosesan data sistem Informasi Geografis, dan terakhir, (Panday, 2015b) telah menggunakan TRAM pada pemrosesan data manajemen proyek di PT.Pembangunan Perumahan. Semua penelitian oleh R.Panday, menunjukkan hasil yang berbeda satu sama lain, menyebabkan TRAM dan TRI diterapkan dalam kondisi dan subjek yang berbeda.

Melihat penelitian terkait di atas, laporan penelitian dalam makalah ini adalah implementasi TRAM untuk proyek mekanik dan listrik di perusahaan Kontraktor, untuk melihat tingkat kesiapan teknologi dan penerimaan teknologi karyawan, dan pengaruhnya. Penelitian ini memiliki kondisi yang berbeda dibandingkan dengan penelitian sebelumnya.

\section{METODE PENELITIAN}

Metode yang digunakan dalam penelitian ini adalah metode kuantitatif. Data diambil menggunakan kuesioner, dengan skala lickert, yang merupakan modifikasi dan penyesuaian dari kuesioner yang dibuat oleh Parasuraman dan Davis. Populasi responden adalah Karyawan PT DENKI yang berada dikantor pusat maupun yang berkantor di proyek dengan total 850 orang. Dengan menggunakan rumus slovin, dan error $=0.1$, maka didapatkan sampel sebesar 89,5, dibulatkan menjadi 90. Kuesioner yang disebarkan kepada responden sebanyak 125, yang kembali sebanyak 112, yang mengisi kuesioner semua pertanyaan adalah 105 . Yang dipakai dalam hitungan adalah 100 kuesioner. Data kuesioner tersebut sebagai penguji model TRAM seperti yang ditunjukkan pada Gambar 1 . Pemrosesan data menggunakan analisis jalur dalam perangkat lunak Amos versi 18.

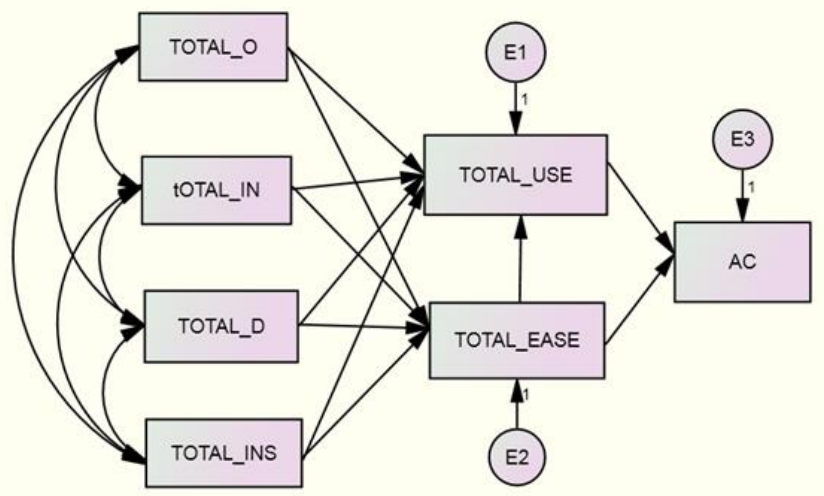

Keterangan:

TOTAL_O: Optimisme

TOTAL_IN: Keinovasian

TOTAL_d: Ketidaknyamanan

TOTAL-INS: Ketidakamanan

TOTAL_USE: Persepsi kegunaan

TOTAL_EASE: Persepsi kemudahan

mengunakan

AC: Intensi penggunaan.

Gambar 1. model penelitian TRAM 


\section{HASIL DAN PEMBAHASAN}

Sebelum melakukan analisis jalur, kuesioner diuji terlebih dahulu menggunakan analisa validitas dan reliabilitas. Hasil validitas pada tabel-1.

Tabel 1. Hasil Validitas Kesiapan Teknologi dan Penerimaan Teknologi

\begin{tabular}{|c|c|c|c|c|c|c|c|c|c|}
\hline \multicolumn{10}{|c|}{ Pearson Correlation } \\
\hline 01 & 02 & 03 & 04 & 05 & 06 & 07 & 08 & 09 & 010 \\
\hline $.754^{* *}$ & $.764^{* *}$ & $.693^{* *}$ & $.729^{* *}$ & $.765^{* *}$ & $.689^{* *}$ & $.781^{* *}$ & $.748^{* *}$ & $.842^{* *}$ & $.771^{* *}$ \\
\hline IN1 & IN2 & IN3 & IN4 & IN5 & IN6 & IN7 & & & \\
\hline $.797^{* *}$ & $.874^{* *}$ & $.799^{* *}$ & $.770^{* *}$ & $.747^{* *}$ & $.793^{* *}$ & $.748^{* *}$ & & & \\
\hline D1 & $\mathrm{D} 2$ & D3 & D4 & D5 & D6 & D7 & D8 & D9 & D10 \\
\hline $.817^{* *}$ & $.814^{* *}$ & $.757^{* *}$ & $.779^{* *}$ & $.845^{* *}$ & $.893^{* *}$ & $.665^{* *}$ & $.707^{* *}$ & $.766^{* *}$ & $.770^{* *}$ \\
\hline INS1 & INS2 & INS3 & INS4 & INS5 & INS6 & INS7 & INS8 & INS9 & \\
\hline $.766^{* *}$ & $.851^{* *}$ & $.802^{* *}$ & $.854^{* *}$ & $.810^{* *}$ & $.859^{* *}$ & $.813^{* *}$ & $.820^{* *}$ & $.794^{* *}$ & \\
\hline USE1 & USE2 & USE3 & USE4 & USE5 & USE6 & & & & \\
\hline $.780^{* *}$ & $.772^{* *}$ & $.838^{* *}$ & $.786^{* *}$ & $.768^{* *}$ & $.769^{* *}$ & & & & \\
\hline EASE1 & EASE2 & EASE3 & EASE4 & EASE5 & EASE6 & & & & \\
\hline $.795^{* *}$ & $.804^{* *}$ & $.775^{* *}$ & $.857^{* *}$ & $.871^{* *}$ & $.770^{* *}$ & & & & \\
\hline
\end{tabular}

Dari hasil perhitungan validitas, semua indikator alpha Cronbach lebih besar dari 0,6, sehingga variabel menunjukkan nilai signifikan, sehingga dapat dikatakan bahwa kuesioner yang hasil kuesioner valid. Hasil perhitungan digunakan reliabel. reliabilitas ditunjukkan pada tabel 2 , bahwa nilai

Tabel 2. Perhitungan hasil reliabilitas

\begin{tabular}{|c|c|c|c|c|c|}
\hline \multicolumn{6}{|c|}{ Cronbach's Alpha } \\
\hline Optimism & $\begin{array}{c}\text { Innovativene } \\
\text { SS }\end{array}$ & $\begin{array}{c}\text { Discomfo } \\
\text { rt }\end{array}$ & $\begin{array}{c}\text { Insecurit } \\
\mathrm{y} \\
\end{array}$ & $\begin{array}{c}\text { Perceive } \\
\text { usefulness }\end{array}$ & $\begin{array}{c}\text { Perceive ease } \\
\text { of use }\end{array}$ \\
\hline .915 & .898 & .930 & .938 & .870 & .896 \\
\hline
\end{tabular}

Nilai rata-rata dari setiap variabel kesiapan teknologi dan teknologi penerimaan ditunjukkan pada tabel-3. Nilai rata-rata variabel Optimisme adalah 3,99, itu berarti tinggi, yang berarti bahwa pandangan responden tentang teknologi yang digunakan adalah positif dan mereka percaya itu akan meningkatkan kontrol, fleksibilitas, dan efisiensi dalam hidup mereka. Nilai rata-rata variabel keinovasian adalah 3,85, dikatakan tinggi, artinya responden memiliki kecenderungan sebagai pelopor teknologi dan berpikir ke depan. Karena kedua variabel ini dapat dikatakan tinggi, kedua variabel tersebut merupakan pendorong kuat kesiapan teknologi masing-masing responden. Nilai rata-rata dari variabel ketidaknyamanan adalah 2,98 dan nilai ketidakamanan rata-rata adalah 3,08, masingmasing dapat dikatakan moderat dan tinggi; ini berarti, variabel penghambat dari kesiapan teknologi masih tinggi, sehingga dapat mengurangi nilai kesiapan teknologi secara keseluruhan. Kedua nilai ini seharusnya memiliki nilai rata-rata rendah atau sangat rendah, jika ingin kesiapan teknologi tinggi. 
Tabel 3. Nilai rata-rata kesiapan teknologi dan variabel penerimaan teknologi

\begin{tabular}{|c|c|c|c|c|c|c|c|c|c|}
\hline \multicolumn{10}{|c|}{ Nilai rata-rata } \\
\hline Optimism & \multicolumn{2}{|c|}{ Keinovativan } & \multicolumn{2}{|c|}{$\begin{array}{c}\text { Ketidak- } \\
\text { nyamanan }\end{array}$} & $\begin{array}{l}\text { Ketidak- } \\
\text { amanan }\end{array}$ & \multicolumn{2}{|c|}{$\begin{array}{c}\text { Persepsi } \\
\text { Kemudahan } \\
\text { Menggunakan }\end{array}$} & \multicolumn{2}{|c|}{$\begin{array}{l}\text { Persepsi } \\
\text { kegunaan }\end{array}$} \\
\hline 3.99 & \multicolumn{2}{|c|}{3.85} & \multicolumn{2}{|c|}{2.98} & 3.08 & \multicolumn{2}{|c|}{4.10} & \multicolumn{2}{|c|}{3.96} \\
\hline Tinggi & \multicolumn{2}{|c|}{ Tinggi } & \multicolumn{2}{|c|}{ Moderat } & Tinggi & \multicolumn{2}{|c|}{ Sangat Tinggi } & \multicolumn{2}{|c|}{ Tinggi } \\
\hline \multicolumn{10}{|c|}{ Penjelasan dari skala nilai rata-rata } \\
\hline 0 & \multicolumn{2}{|c|}{1} & & & 3 & \multicolumn{2}{|c|}{4} & & 5 \\
\hline \multicolumn{2}{|c|}{$\begin{array}{l}\text { Sangat } \\
\text { rendah }\end{array}$} & \multicolumn{2}{|c|}{ Rendah } & \multicolumn{2}{|c|}{ Moderat } & ggi & \multicolumn{3}{|c|}{ Sangat Tinggi } \\
\hline
\end{tabular}

Sedangkan nilai penerimaan teknologi Nilai rata-rata dapat dikatakan tinggi, artinya dinyatakan oleh nilai rata-rata variabel penerimaan teknologi responden tinggi. kemudahan penggunaan yang dirasakan dan Respons frekuensi terhadap penggunaan variabel kegunaan yang dirasakan, masing- teknologi memiliki nilai rata-rata 4,26, dapat masing 4.10 (sangat tinggi) dan 3,96 (tinggi). dikatakan tinggi berdasarkan skala pada tabel 4 .

Tabel 4. Rentang Skala penggunaan aktual

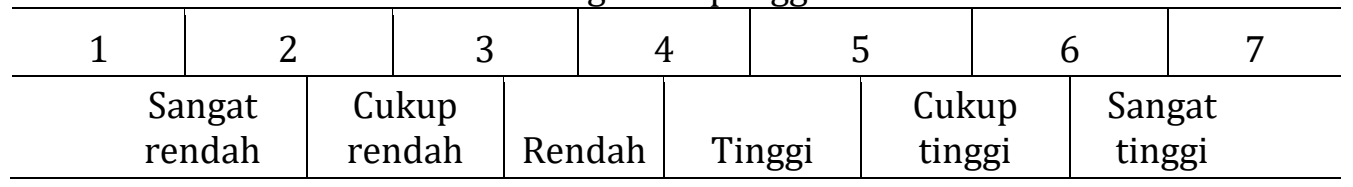

Analisa Jalur

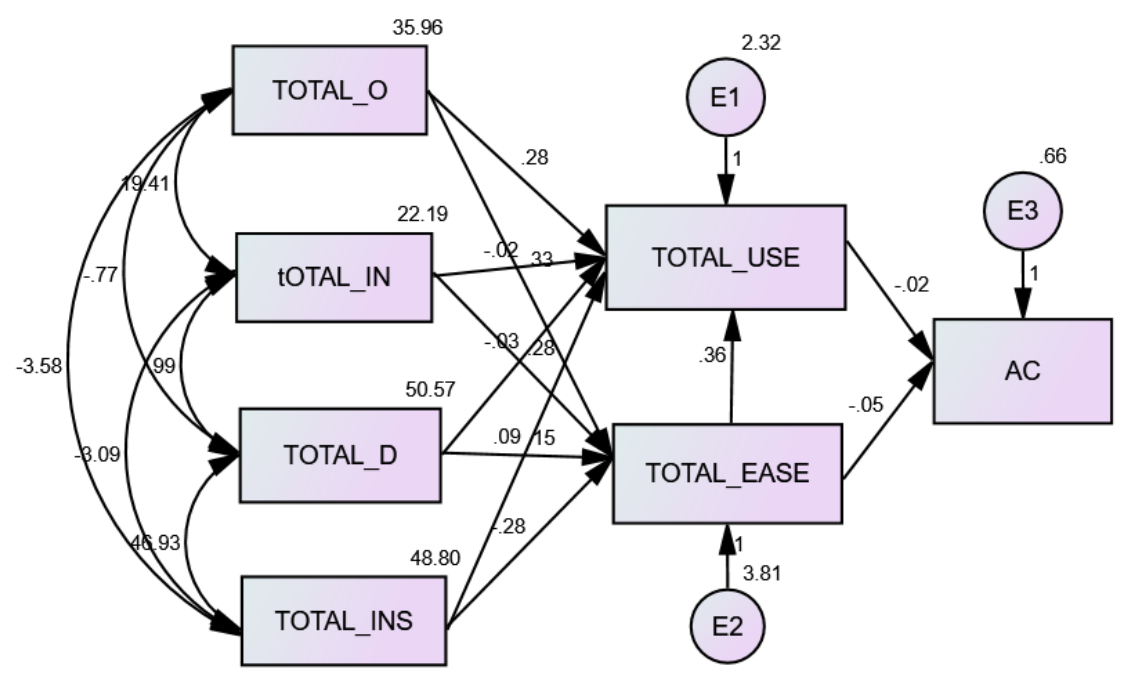

Gambar 2. Hasil Hitungan Regression Weights 
Hasil penelitian ditunjukkan pada Tabel-5 dan Tabel-6, bahwa:

Optimisme berpengaruh positif dan siknifikan terhadap Persepsi Kemudahan Menggunakan, sebanyak 51,2 \%. Keinovasian berpengaruh positif dan siknifikan terhadap Persepsi Kemudahan Menggunakan, sebanyak 33,5\%. Ketidaknyamanan berpengaruh Positif namun tidak siknifikan terhadap Persepsi Kemudahan Menggunakan. Ketidakamanan berpengaruh negatif dan siknifikan terhadap Persepsi Kemudahan Menggunakan, sebanyak 28,2\%. Optimisme berpengaruh positif dan siknifikan terhadap persepsi kegunaan, sebanyak 53,2 \%
Ketidakamanan berpengaruh positif namun tidak siknifikan terhadap persepsi kegunaan. Ketidaknyamanan berpengaruh negatif namun tidak siknifikan terhadap persepsi kegunaan. Ketidakamanan berpengaruh positif namun tidak siknifikan terhadap persepsi kegunaan. Persepsi Kemudahan Menggunakan berpengaruh positif dan siknifikan terhadap persepsi kegunaan, sebanyak $44,6 \%$

Persepsi Kemudahan Menggunakan berpengaruh negatif namun tidak siknifikan terhadap intensitas penggunaan. Persepsi kegunaan berpengaruh negatif namun tidak siknifikan terhadap intensitas penggunaan.

Tabel 5. Hasil Hitungan Regression Weights

\begin{tabular}{|c|c|c|c|c|c|c|c|}
\hline & & & Estimasi & S.E. & C.R. & $\mathrm{P}$ & Label \\
\hline $\begin{array}{l}\text { Persepsi Kemudahan } \\
\text { Menggunakan }\end{array}$ & $<---$ & Optimisme & .332 & .045 & 7.341 & $* * *$ & \\
\hline $\begin{array}{l}\text { Persepsi Kemudahan } \\
\text { Menggunakan }\end{array}$ & $<---$ & Keinovativan & .277 & .061 & 4.569 & $* * *$ & \\
\hline $\begin{array}{l}\text { Persepsi Kemudahan } \\
\text { Menggunakan }\end{array}$ & $<---$ & $\begin{array}{l}\text { Ketidak- } \\
\text { nyamanan }\end{array}$ & .154 & .091 & 1.702 & .089 & \\
\hline $\begin{array}{l}\text { Persepsi Kemudahan } \\
\text { Menggunakan }\end{array}$ & $<---$ & Ketidak-amanan & -.278 & .093 & -3.002 & .003 & \\
\hline Persepsi kegunaan & $<---$ & Optimisme & .282 & .044 & 6.438 & $* * *$ & \\
\hline Persepsi kegunaan & $<---$ & Keinovativan & -.021 & .052 & -.405 & .686 & \\
\hline Persepsi kegunaan & $<---$ & $\begin{array}{l}\text { Ketidak- } \\
\text { nyamanan }\end{array}$ & -.034 & .072 & -.481 & .631 & \\
\hline Persepsi kegunaan & $<---$ & Ketidak-amanan & .090 & .075 & 1.192 & .233 & \\
\hline Persepsi kegunaan & $<---$ & $\begin{array}{l}\text { Persepsi } \\
\text { Kemudahan } \\
\text { Menggunakan }\end{array}$ & .365 & .078 & 4.651 & $* * *$ & \\
\hline $\mathrm{AC}$ & $<---$ & $\begin{array}{l}\text { Persepsi } \\
\text { kegunaan }\end{array}$ & -.024 & .042 & -.572 & .567 & \\
\hline $\mathrm{AC}$ & $<---$ & $\begin{array}{l}\text { Persepsi } \\
\text { Kemudahan } \\
\text { Menggunakan }\end{array}$ & -.052 & .034 & -1.506 & .132 & \\
\hline
\end{tabular}




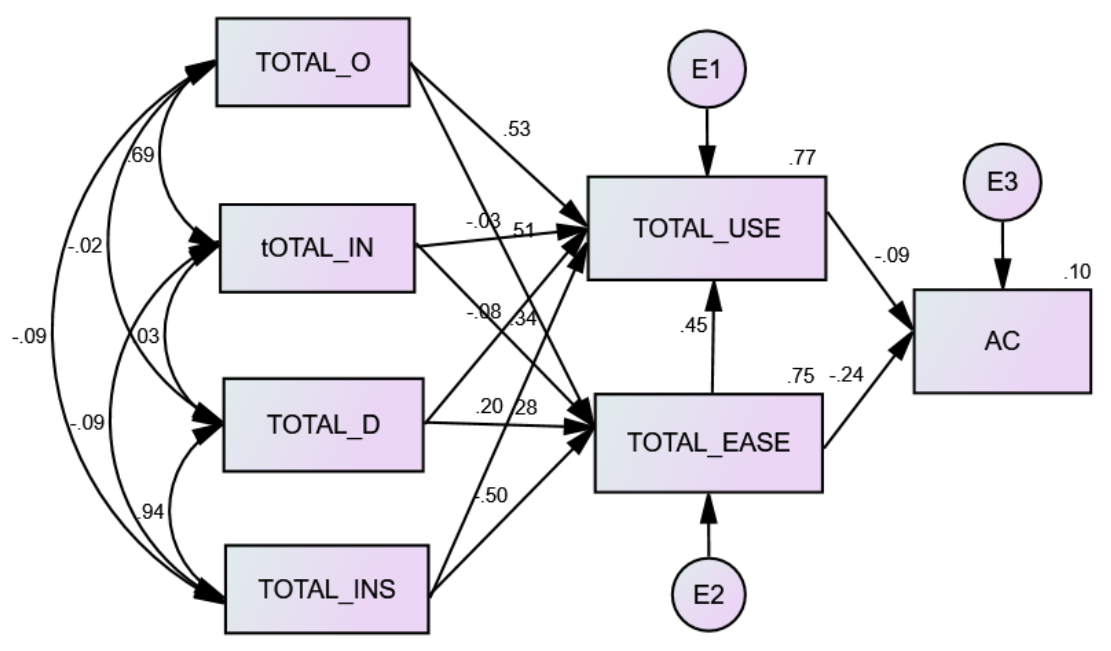

Gambar 3. Hasil Hitungan Standardized Regression Weights

Tabel 6. Hasil Hitungan Standardized Regression Weights

\begin{tabular}{lllr}
\hline & & Nilai-Estimasi \\
\hline Persepsi Kemudahan Menggunakan & $<--$ & Optimisme & .512 \\
\hline Persepsi Kemudahan Menggunakan & $<---$ & Keinovativan & .335 \\
\hline Persepsi Kemudahan Menggunakan & $<---$ & Ketidak-amanan & .282 \\
\hline Persepsi Kemudahan Menggunakan & $<---$ & Ketidak-nyamanan & -.499 \\
\hline Persepsi kegunaan & $<---$ & Optimisme & .532 \\
\hline Persepsi kegunaan & $<---$ & Keinovativan & -.031 \\
\hline Persepsi kegunaan & $<---$ & Ketidak-amanan & -.077 \\
\hline Persepsi kegunaan & $<---$ & Ketidak-nyamanan & .198 \\
\hline Persepsi kegunaan & $<---$ & Persepsi Kemudahan Menggunakan & .446 \\
\hline AC & $<---$ & Persepsi kegunaan & -.089 \\
\hline AC & $<---$ & Persepsi Kemudahan Menggunakan & -.236 \\
\hline
\end{tabular}

Melihat Tabel-7, kontribusi variabel kesiapan persepsi kegunaan sebanyak 77,0\%. Kontribusi teknologi pada persepsi kemudahan penerimaan teknologi pada penggunaan aktual penggunaan sebanyak 74,8\%, sedangkan sebanyak 9,7\%.

kontribusi variabel kesiapan teknologi terhadap 
Tabel 7. Hasil hitungan R square

\begin{tabular}{lr}
\hline & Estimate \\
\hline Persepsi Kemudahan Menggunakan & .748 \\
\hline Persepsi kegunaan & .770 \\
\hline Aktual Penggunaan & .097 \\
\hline
\end{tabular}

Penggunaan teknologi TIK di PT. DENKI, dalam hal ini teknologi dan perangkat lunak komputer, berdasarkan penelitian ini, kesiapan teknologi karyawannya memiliki karakteristik Optimisme, Keinovasian, Ketidaknyamanan, dan Ketidakamanan. Tingginya skor Optimisme dan Keinovasian sebagai faktor pendorong tingkat kesiapan teknologi adalah tinggi, sedangkan skor faktor Ketidaknyamanan dan Ketidakamanan juga tinggi sebagai merupakan faktor penghambat tingkat kesiapan teknologi. Karyawan dalam proyek ini secara umum, masih memiliki Ketidaknyamanan yang tinggi dalam menggunakan teknologi, dan juga masih memiliki Ketidakamanan yang tinggi dalam menggunakan TIK. Oleh karena itu perusahaan harus dapat memberikan kenyamanan kepada karyawannya dalam menggunakan teknologi tersebut, seperti menggunakan komputer dan perangkat lunak yang pada dasarnya menyederhanakan dan memudahkan pekerjaan. Demikian juga perusahaan harus dapat memberikan rasa aman kepada karyawannya, seperti memberikan penjelasan bahwa data yang telah diproses, dapat disimpan dengan aman, dan tidak perlu khawatir jika data akan hilang atau rusak. Meskipun memiliki faktor penghambat yang tinggi pada kesiapan teknologi, kontribusi kesiapan teknologi terhadap persepsi kemudahan dalam menggunakan teknologi tinggi sebanyak 74,8\% dan kontribusi terhadap persepsi kegunaan teknologi tinggi yaitu $77,0 \%$. Selanjutnya, penerimaan teknologi dari PT. Karyawan DENKI, dalam hal ini persepsi kemudahan penggunaan tenologi adalah tinggi, demikian juga tentang persepsi tentang kegunaan teknologi. Intensitas penggunaan teknologi di PT. DENKI tergolong tinggi, walaupun intensitas penggunaan teknologi merupakan kontribusi penerimaan teknologi sebanyak 9,7\%. Tingginya intensitas penggunaan teknologi dalam proyek tidak disebabkan oleh faktor penerimaan teknologi tinggi, dan penerimaan teknologi tidak berpengaruh positif dan siknifikan terhadap intensitas penggunaan. Ini berarti bahwa intensitas tinggi disebabkan oleh hal-hal lain, atau variable lain selain variable penerimaan teknologi, seperti situasi yang memaksa karyawan untuk bekerja menggunakan teknologi dan perangkat lunak komputer. Dengan demikian dalam penelitian ini terdapat penyimpangan dari teori TRA, yang menyatakan bahwa intensitas penggunaan teknologi yang tinggi disebabkan oleh penerimaan teknologi yang tinggi.

\section{IMPLIKASI MANAJERIAL}

Berdasarkan diskusi di atas, PT, DENKI, harus merencanakan beberapa program strategis untuk mengatasi variabel Ketidaknyamanan dan Ketidakamanan pada karyawan dengan memberi mereka beberapa pelatihan terkait jenis teknologi yang mereka gunakan secara teratur. Misalnya, merencanakan pelatihan cara menggunakan perangkat lunak Excel lebih efektif dengan menggunakan banyak perintah yang sudah ada dalam perangkat lunak, pelatihan cara menggunakan perangkat lunak manajemen proyek dalam mengatur jadwal kerja agar lebih efisien dengan biaya perencanaan proyek dan personal incharge dalam menangani pekerjaan tertentu, dll. Dengan adanya pelatihan tersebut, maka karyawan dapat menggunakan hardware dan software yang terkait dengan mudah dan percaya akan kegunaannya yang akan membantu pekerjaan proyek. Selain itu, PT, DENKI, harus memberikan supervisi kepada karyawan, ketika mereka menggunakan teknologi TIK, untuk meyakinkan bahwa teknologi itu nyaman dan aman. Dan yang terakhir, PT.DENKI selalu memperkenalkan kepada karyawan teknologi terbaru, agar karyawan PT.DENKI selalu terdepan dalam menggunakan teknologi terbaru. 


\section{KESIMPULAN}

Berdasarkan analisis, dapat disimpulkan bahwa Kesiapan teknologi dan penerimaan teknologi di PT. DENKI memiliki tingkat yang tinggi terhadap implementasi TIK di proyek tetapi kurang berkontribusi terhadap frekuensi menggunaan TIK. Optimisme berpengaruh positif dan siknifikan terhadap perceived ease of use, sebanyak 51,2 \%. Innovativeness berpengaruh positif dan siknifikan terhadap perceived ease of use, $33,5 \%$. Insecurity berpengaruh negatif dan siknifikan terhadap perceived ease of use, sebanyak $28,2 \%$. Optimisme berpengaruh positif dan siknifikan terhadap perceived of usefulness, sebanyak 53,2 $\%$ Perceived ease of use berpengaruh positif dan siknifikan terhadap perceived of usefulness, sebanyak 44,6\% Kontribusi variabel kesiapan teknologi pada persepsi kemudahan penggunaan tinggi, sebanyak $74,8 \%$ Kontribusi variabel kesiapan teknologi pada persepsi kegunaan tinggi, sebanyak $77,0 \%$ Kontribusi penerimaan terhadap penggunaan aktual sebesar 9,7\%.

\section{SARAN}

Penelitian berikutnya disarankan focus pada dampak dari Kinerja Manajerial pada pertumbuhan perusahaan.

\section{DAFTAR PUSTAKA}

Anders Husa, M. K. (2009). The TRAM Framework in a Social Media Context Measuring Attitudes Towards ConsumerCompany Interaction" A Study of Norwegian Social Media Users. Retrieved from http://andershusa.files.wordpress.com/20 10/03/master-thesisfinal.pdf

Burton-Jones, A., \& Hubona, G. S. (2006). The mediation of external variables in the technology acceptance model. https://doi.org/10.1016/j.im.2006.03.007

Davis, D., Bagozzi, R. P., \& Warshaw, P. R. (1989). User acceptance of computer technology: A comparison of two theoretical models. https://doi.org/10.1287/mnsc.35.8.982

Davis, F. D. (1989). Perceived usefulness, perceived ease of use, and user acceptance of information technology. MIS Quarterly, 13 , 319-340. https://doi.org/10.2307/249008

Fishbein, M., \& Ajzen, I. (1975). Belief, attitude, intention, and behavior: An introduction to theory and research. Reading,.

Kerzner, H. (1998). Project Management, a System Approach to Planning, Scheduling and Controlling. Canada: John Willey \& Sons, Inc.

King, W. R., \& He, J. (2006). A meta-analysis of the technology acceptance model. https://doi.org/10.1016/j.im.2006.05.003

Kuang-Ming Kuo, C.-F. L. and C.-C. M. (2013). An investigation of the effect of nurses'technology readiness on the acceptance of mobile electronic medical record systems. BMC Medical Informatics and Decision Making.

Lin, C.-H., Shih, H.-Y., Sher, P. J., \& W. Y.-L. (2005). Consumer adoption of e-service: Integrating technology readiness with the technology acceptance model. In Proceedings of PICMET '05: Technology Management: A Unifying Discipline for Melting the Boundaries (pp. 483-488). Portland, Oregon, USA. https://doi.org/10.1109/PICMET.2005.15 09728

Malhotra, Y., \& Galletta, D. F. (1999). Extending the technology acceptance model to account for social influence: Theoretical bases and empirical validation. In . Proceedings of the 32nd Hawaii International Conference on System Sciences, Maui, Hawaii, USA, 114. https://doi.org/10.1109/HICSS.1999.7726 58

Meredith, Jack.R and Mantel, S. J. (1995). Project Management, A managerial Approach. Canada: John Willey \& Sons, Inc.

Mimin Nur Aisyah, Mahendra Adhi Nugroho, E. M. S. (2013). Pengaruh Technology Readiness Terhadap Penerimaan Teknologi komputer Pada UMKM di Yogyakarta. Retrieved from http://staff.uny.ac.id/sites/default/files/pe nelitian/Endra Murti Sagoro, S.E.,M.Sc./Pengaruh Technology Readiness 
Te rhadap Penerimaan Teknologi Komputer pada UMKM di Yogyakarta.pdf

Murat Esen, N. E. (2014). Effects of Technology Readiness On Technology Acceptance In EHRM: Mediating Role of Perceived Usefulness. Retrieved from http://www.beykon.org/dergi/ 2014/SPRING/M.Esen.pdf

Nadine Guhr, Tai Loi, Rouven Wiegard, and M. H. B. (2013). Technology Readiness in Customers' Perception and Acceptance of M(obile)-Payment: An Empirical Study in Finland, Germany, the USA and Japan. In Germany 11th International Conference on Wirtschafts informatic, 27thFebruary - 01st March 2013. Leipzig, Germany. Retrieved from

http://www.wi2013.de/proceedings/WI20 13 Track 1 - Guhr.pdf.

Nicholas, J. M. (1990). Managing Business \& Engineering Projects, Concepts \& Implementation. USA: Prentice Hall, Inc.

Panday, R. (2015a). Analysis of technology readiness and technology acceptance of geodesy student in using ina geoportal, (November), 10-12.

Panday, R. (2015b). Evaluation of Technology Readiness-Acceptance in Operation of Project Management Services. Banda Aceh, Indonesia: Presenting and publishing in proceeding, at 1st Joint Conference Indonesia Malaysia, Bangladesh and Ireand at Ubudiyah Indonesia University.

Panday, R. (2015c). The Effect of Technology Readiness on Technology Acceptance in Using Services Delivery of Academic Information System (pp. 978-979).

Panday, R., \& Purba, J. T. (2015). Lecturers and students technology readiness in implementing services delivery of academic information system in higher education institution: A case study. In Communications in Computer and Information Science (Vol. 516, pp. 539550). https://doi.org/10.1007/978-3-66246742-8_49

Parasuraman, A., \& Colby, C. L. (2001). Technoready marketing: How and why your customers adopt technology. New York: Free Press.
Parasuraman, A. (2000a). Technology readiness index (TRI): A multiple-item scale to measure readiness to embrace new technologies. Journal of Service Research, 2. https://doi.org/10.1177/1094670500240 01

Parasuraman, A. (2000b). Technology readness index (TRI) a multiple-item scale to embrace new technologies. Journal of Service Research, 2(4), 307-320. https://doi.org/10.1177/1094670500240 01

PMBOK Guide. (1996). A Guide ProJect Management Body of Knowledge. USA: Project Management Institute Standards Committee.

Setyawati, I., Purnomo, A., Irawan, D. E., Tamyiz, M., \& Sutiksno, D. U. (2018). A Visual Trend of Literature on Ecopreneurship Research Overviewed within the Last Two Decades.Journal of Entrepreneurship Education.

Schepers, J., \& Wetzels, M. (2007). A metaanalysis of the technology acceptance model: Investigating subjective norm and moderation effects. Information \& Management, $\quad$ 90-103. https://doi.org/10.1016/j.im.2006.10.007

Tsikriktsis, N. (2004). A technology readinessbased taxonomy of costumers: A replication and extension. Journal of Service Research, $4, \quad 42=45$. https://doi.org/10.1177/1094670504266 132

Venkatesh, V. (2000). Determinants of perceived ease of use: Integrating control, intrinsic motivation, and emotion into the technology acceptance model. Information Systems Research, 342-365. https://doi.org/10.1287/isre.11.4.342.118 72

Yen, J. (2014). Perspectives from the TRAM Model on Adopting e-Learning: An Analysis of the Chain and Franchise Industry in Taiwa, (25januari 2015).

Widyaningrum, H., Setyawati, I., \& Maryati, Y. (2018). Pencegahan terhadap Pelanggaran Hak Perempuan Sebagai Pekerja berdasarkan Undang-Undang Nomor 13 Tahun 2003. Jurnal ABDIMAS (Pengabdian 
44 | Analisis Itechnology Readiness Acceptance Penggunaan Komputer dan Teknologi Informasi pada Manajemen proyek Kontraktor oleh $R$ panday et al.

kepada Masyarakat) UBJ, 1(2). 